\title{
PERTIMBANGAN HAKIM DALAM PENJATUHAN PIDANA KEPADA ANAK YANG MELAKUKAN TINDAK PIDANA NARKOTIKA (Studi Putusan Pengadilan Negeri Stabat No. 10/Pid.Sus Anak/2015/PN.Stb)
}

\author{
${ }^{1}$ Achmad Ratomi dan ${ }^{2}$ Khairunnisa \\ 1,2Fakultas Hukum ULM Banjarmasin - Polres Barito Kuala \\ 1ratomi79ach@gmail.com \\ 2nisyadtn43@gmail.com
}

\section{Abstract}

The research aimed to analyze the legal basis applied by the Panel of Judges and the type of crime imposed by the Panel of Judges in the Decision of the District Court of Stabat No 10/Pid.Sus Anak/2015/PN had been appropriate. The result of the research showed from the second indictment that the Public prosecutor charged with article 114 paragraph (2) of the Narcotics act while the Panel Judges in their deliberations outlined the elements of a criminal act contained in article 112 paragraph (1) of the Narcotics law, in the form of possessing without permission. In addition, the Panel of Judges stated in their decision that the defendant was legally and convincingly proven to be an intermediary in buying and selling. However, there was discrepancy in their consideration that the proper criminal to be imposed was criminal oversight as regulated in article 71 paragraph (1) letter $b$ number 3 and article 77 paragraph (2) of low number 11 year 2012, while in their decision, they sentenced the defendant to imprisonment and fines. Nevertheless, the imposition of criminal fines was contrary to the article 71 paragraph (3) Low number 11 year 2012.

Keywords: Narcotics, Judges' Consideration, Children's Crime,.

\section{Abstrak}

Penelitian bertujuan untuk menganalisis dasar hukum yang diterapkan oleh Majelis Hakim dan jenis pidana yang dijatuhkan oleh Majelis Hakim dalam Putusan Pengadilan Negeri Stabat No. 10/Pid.Sus Anak/2015/PN.Stb telah tepat. Dari penelitian tersebut diperoleh hasil di dalam dakwaan yang kedua Jaksa Penuntut Umum mendakwa dengan Pasal 114 ayat (2) UU Narkotika, sementara Majelis Hakim di dalam pertimbangannya menguraikan tentang unsur-unsur tindak pidana yang terdapat di dalam Pasal 112 ayat (1) UU Narkotika, yaitu dalam bentuk memiliki tanpa izin. Padahal di dalam amar putusannya Majelis Hakim menyatakan bahwa terdakwa terbukti secara sah dan meyakinkan menjadi perantara dalam jual beli. Dan terdapat ketidaksesuaian yaitu pada pertimbangnnya Majelis Hakim menilai bahwa pidana yang tepat untuk dijatuhkan adalah pidana pengawasan sebagaimana diatur di dalam Pasal 71 ayat (1) huruf b angka 3 dan Pasal 77 ayat (2) UU No. 11 Tahun 2012, sementara di dalam amar putusannya Majelis Hakim menjatuhkan pidana penjara dan denda. Penjatuhan pidana denda itu bertentangan dengan Pasal 71 ayat (3) UU No. 11 Tahun 2012.

Kata Kunci: Narkotika, Pertimbangan Hakim, Pidana Anak 


\section{PENDAHULUAN}

Narkotika merupakan zat atau obat yang sangat bermanfaat dan diperlukan untuk pengobatan penyakit tertentu. Namun, jika disalahgunakan atau digunakan tidak sesuai dengan standar pengobatan dapat menimbulkan akibat yang sangat merugikan bagi perseorangan atau masyarakat khususnya generasi muda. Hal ini akan lebih merugikan jika disertai dengan penyalahgunaan dan peredaran gelap Narkotika yang dapat mengakibatkan bahaya yang lebih besar bagi kehidupan dan nilai-nilai budaya bangsa yang pada akhirnya akan dapat melemahkan ketahanan nasional.

Adapun yang dimakud narkotika dalam Undang-Undang Nomor 35 Tahun 2009 tentang Narkotika adalah tanaman papever, opium mentah, opium masak, seperti candu, jicing, jicingko, opium obat, morfina, tanaman koka, daun koka, kokaina mentah, kokaina, ekgonina, tanaman ganja, damar ganja, garam-garam atau turunannya dari morfin dan kokaina. Bahan lain, baik alamiah, atau sitensis maupun semi sitensis yang belum disebutkan yang dapat dipakai sebagai pengganti morfina atau kokaina yang ditetapkan mentri kesehatan sebagai narkotika, apabila penyalahgunaannya dapat menimbulkan akibat ketergantungan yang merugikan, dan campuran-campuran atau sediaan-sediaan yang mengandung garam-garam atau turunan-turunan dari morfina dan kokaina, atau bahan-bahan lain yang alamiah atau olahan yang ditetapkan mentri kesehatan sebagai narkotika.

Pada saat ini narkotika sudah merambah kepada setiap kalangan. Bahkan penyalahgunaan narkotika yang dilakukan oleh anak sudah sering terjadi sehingga sudah sampai pada tingkatan yang meresahkan masyarakat. Anak yang seharusnya bisa bebas dari segala bentuk tindak pidana narkotika, malahan bisa terjerumus di dalam peredaran gelap narkotika.

Salah satu contoh kasus keterlibatan anak dalam jaringan peredaran gelap narkotika adalah sebagaimana yang terjadi di Stabat Kabupaten Langkat Sumatera Utara. Bahwa ia anak MJ, pada hari Kamis tanggal 150ktober 2015 sekitar pukul 04.30 wib atau setidak-tidaknya pada waktu lain dalam bulan Oktober 2015 atau pada tahun 2015 bertempat di Depan Pos Lantas Polsek Gebang di Jalan Lintas sumatera Dusun III Desa Paluh ManisKecamatan Gebang Kabupaten Langkat atau setidak-tidaknya di suatu tempat yang masih termasuk dalam daerah hukum Pengadilan Negeri Stabat, tanpa hak atau melawan hukum membawa, mengirim, mengangkut, atau mentransito Narkotika Golongan Idalam bentuk tanaman yang beratnya melebihi 1(satu) kilogram atau melebihi 5(lima) batang pohon beratnya melebihi 5 (lima) gram.

Perbuatan tersebut dilakukan pada waktu dan tempat tersebut di atas, bermula ketika saksi Nazri Lubis, saksi Anggiat Simanjuntak dan saksi Aldolf Simanjuntak(ketiga saksi anggota Polri Polsek Gebang) bersama personil Polsek Gebang melakukan sweeping terhadap kendaraan yang lewat. Saat itu para saksi polisi menghentikan bus PT. Putra Pelangi Perkasa BL.7520.AA, kemudian saksi Anggiat Simanjuntak dan saksi Aldolf Simanjuntak masuk ke dalam bus dan melakukan pemeriksaanterhadap bawaan 
para penumpang bus, ketika sampai pada tempat duduk nomor $21 / 22$, dimana anak Muhajir alis Bulek duduk, saksi Anggiat Simanjuntak dan saksi Aldolf Simanjuntak meminta anak untuk membuka tas ransel hitam merk Elgini milik anak, ketika dibuka ditemukan 4 (empat) bal Narkotika Golongan I jenis ganja kering dibalut lakban kuning, ketika ditanya dimana lagianak simpan ganja tersebut, anak mengaku menyimpan ganja dalam kardus pop mie di bagasi bus sebelah kiri, kemudian anak dibawa untuk menunjukkan kardus bawannya, dan ketika dibuka kardus bawaan anak tersebut ditemukan lagi barang bukti berupa Narkotika Golongan I jenis Ganja sebanyak 11 bal yang dibalut lakban kuning. Ketika ditanya, anak mengaku bahwa 15 bal ganja kering tersebut dibawa dari Sawang (Aceh) menuju Medan dan ganja tersebut milik Hamdan (DPO) sedangkan anak hanya bertugas sebagai kurir dengan upah Rp.100.000,-(seratus ribu rupiah) per kilogram atau per bal nya. Karena tidak memiliki izin anak dan barang bukti berupa 15 bal Narkotika golongan I jenis ganja dibawa ke Polsek Gebang untuk diperiksa lebih lanjut. Berdasarkan berita acara penimbangan barang bukti dari PT.Pegadaian Pangkalan Brandan No: 30/IL.010700/IX/2015 tanggal 15 Oktober 2015 dengan hasil penimbangan barang bukti berupa 15 bal/bungkus besar yang diduga berisikan Narkotika jenis ganja kering dengan berat kotor 16.500 (enam belas ribu lima ratus) gram yang disisihkan untuk keperluan Laboratorium Narkotika Medan seberat 129 (seratus dua puluh sembilan) gram dan Berita Acara Analisis Laboratorium Barang Bukti Narkotika Medan No. Lab: 9580/NNF/2015 tanggal 19 Oktober 2015 yang dibuat, diperiksa dan ditanda tangani oleh Zulni Erma dan Deliana Nairbohu, S.Si., Apt menyimpulkan bahwa barang bukti berupa: 1(satu) plastik bening berisi daun dan biji kering dengan berat netto 129 (seratus dua puluh sembilan) gram dan pengembalian barang bukti sesudah labfor dengan berat netto 125 (seratus dua puluh lima) gramgram milik tersangka Muhajir Alias Bulek adalah benar positif Ganja dan terdaftar dalam golongan I(satu) nomor urut 8 Lampiran I Undang-Undang RI No. 35 tahun 2009 tentang Narkotika, sertaBerita Acara Analisis Laboratorium Barang Bukti Narkotika Medan No. Lab : 9579/NNF/2015 tanggal 19 Oktober 2015 yang dibuat, diperiksa dan ditanda tangani oleh Zulni Erma dan Deliana Nairbohu, S.Si., Apt menyimpulkan bahwa barang bukti berupa : 1(satu) botol plastik berisi $35 \mathrm{ml}$ urine milik tersangka Muhajir Alias Bulek adalah benar mengandung positif Tetrahydrocannabinol (THC) dan terdaftar dalam golongan I(satu) nomor urut 9 Lampiran I Undang-Undang RI No. 35 tahun 2009 tentang Narkotika.

Berdasarkan pada kronologis itu, Jaksa Penuntut Umum mendakwa MJ dengan dakwaan alternatif:

1. Kesatu : Pasal 115 ayat (2) UU No. 35 Tahun 2009 tentang Narkotika jo. UU No. 11 Tahun 2012 tentang Sistem Peradilan Pidana Anak.

Dalam hal perbuatan membawa, mengirim, mengangkut, atau mentransito Narkotika Golongan I sebagaimana dimaksud pada ayat (1) dalam bentuk tanaman beratnya melebihi 1 (satu) kilogram atau melebihi 5 (lima) batang pohon beratnya melebihi 5 (lima) gram, pelaku dipidana dengan pidana penjara seumur hidup atau pidana penjara paling singkat 5 (lima) tahun dan paling lama 20 (dua puluh) tahun 
dan pidana denda maksimum sebagaimana dimaksud pada ayat (1) ditambah $1 / 3$ (sepertiga).

2. Kedua : Pasal 114 ayat (2) UU No. 35 Tahun 2009 tentang Narkotika jo. UU No. 11 Tahun 2012 tentang Sistem Peradilan Pidana Anak.

Dalam hal perbuatan menawarkan untuk dijual, menjual, membeli, menjadi perantara dalam jual beli, menukar, menyerahkan, atau menerima Narkotika Golongan I sebagaimana dimaksud pada ayat (1) yang dalam bentuk tanaman beratnya melebihi 1 (satu) kilogram atau melebihi 5 (lima) batang pohon atau dalam bentuk bukan tanaman beratnya 5 (lima) gram, pelaku dipidana dengan pidana mati, pidana penjara seumur hidup, atau pidana penjara paling singkat 6 (enam) tahun dan paling lama 20 (dua puluh) tahun dan pidana denda maksimum sebagaimana dimaksud pada ayat (1) ditambah $1 / 3$ (sepertiga).

3. Ketiga : Pasal 111 ayat (2) UU No. 35 Tahun 2009 tentang Narkotika jo. UU No. 11 Tahun 2012 tentang Sistem Peradilan Pidana Anak.

Dalam hal perbuatan menanam, memelihara, memiliki, menyimpan, menguasai, atau menyediakan Narkotika Golongan I dalam bentuk tanaman sebagaimana dimaksud pada ayat (1) beratnya melebihi 1 (satu) kilogram atau melebihi 5 (lima) batang pohon, pelaku dipidana dengan pidana penjara seumur hidup atau pidana penjara paling singkat 5 (lima) tahun dan paling lama 20 (dua puluh) tahun dan pidana denda maksimum sebagaimana dimaksud pada ayat (1) ditambah $1 / 3$ (sepertiga).

Dalam kasus itu Majelis Hakim melalu Putusan Pengadilan Negeri Stabat No. 10/Pid.Sus Anak/2015/PN.Stb menjatuhkan putusan berupa menyatakan MJ terbukti secara sah dan meyakinkan bersalah melakukan tindak pidana"Tanpa hak dan melawan hukum menjadi perantara jual beli Narkotika Golongan I dalam bentuk tanaman", sebagaimana dalam dakwaan Pasal 114 ayat(2) Undang Undang RI No. 35 tahun2009 tentang Narkotika Jo Undang Undang RI No. 11 Tahun 2012 tentang Sistem Peradilan Anak. Menjatuhkan pidana terhadap anak Muhajir Alias Bulekoleh karena itu dengan pidana penjara selama 4(empat) tahun dan denda sebesar Rp. 1.000.000.000,-(satu milyar rupiah) dengan ketentuan apabila anak tidak membayar denda tersebut akan diganti dengan menjalani pelatihan kerja selama 2(dua) bulan.

Berdasarkan pada uraian di atas, maka penulis mencoba untuk membahas tentang analisis terhadaap Putusan Pengadilan Negeri Stabat No. 10/Pid.Sus Anak/2015/PN.Stb yang akan dihubungkan dengan penerapaan pasalnya dan jenis pidana yang dijatuhkannya dengan rumusan masalahnya adalah (1) Apakah dasar hukum yang diterapkan oleh Majelis Hakim dalam Putusan Pengadilan Negeri Stabat No. 10/Pid.Sus Anak/2015/PN.Stb telah tepat? Dan (2) Apakah jenis pidana yang dijatuhkan oleh Majelis Hakim dalam Putusan Pengadilan Negeri Stabat No. 10/Pid.Sus Anak/2015/PN.Stb telah tepat?. 


\section{HASIL DAN PEMBAHASAN}

\section{Dasar Hukum yang Diterapkan oleh Majelis Hakim dalam Putusan Pengadilan Negeri Stabat No. 10/Pid.Sus Anak/2015/PN.Stb}

Di dalam KUHAP tidak menetapkan bagaimana bentuk surat dakwaan yang dibuat oleh penuntut umum. Mengenai bentuk-bentuk surat dakwaan adalah merupakan produk yang timbul dari ilmu pengetahuan hukum dan praktek peradilan. Ada beberapa bentuk perumusan dakwaan di dalam surat dakwaan, yaitu (Harahap, 2009: 398-404):

a. Dakwaan Tunggal/Biasa

Bentuk surat dakwaan biasa adalah surat dakwaan yang disusun dalam rumusan "tunggal". Surat dakwaan hanya berisi satu saja dakwaan. Umumnya perumusan dakwaan tunggal dijumpai dalam tindak pidana yang jelas serta tindak mengandung fakta "penyertaan" (mededaderschap) atau faktor concursus maupun faktor "alternatif" atau factor "subsidair". Baik pelakunya maupun tindak pidana yang dilanggar sedemikian rupa jelas dan sederhana, sehingga surat dakwaan cukup dirumuskan dalam bentuk tunggal. Hal ini berarti bahwa penyusunan surat dakwaan tunggal mempunyai sifat sederhana yaitu sederhana dalam perumusannya maupun sederhana dalam pembuktian dan penerapan hukumnya.

b. Dakwaan Alternatif

Surat dakwaan ini didakwakan beberapa perumusan tindak pidana, tetapi pada hakekatnya yang merupakan tujuan utama ialah hanya ingin membuktikan satu tindak pidana saja diantara tindak pidana yang didakwakan. Dakwaan ini digunakan dalam hal antara kualifikasi tindak pidana yang satu dengan kualifikasi tindak pidana yang lain menunjukkan corak atau ciri yang sama atau hampir bersamaan dan bila belum didapat keputusan tentang tidak pidana mana yang paling tepat dapat dibuktikan. Dalam dakwaan ini terdapat beberapa dakwaan yang disusun secara berlapis, lapisan yang satu merupakan alternatif dan bersifat mengecualikan dakwaan pada lapisan lainnya. Meskipun dakwaan terdiri dari beberapa lapisan, tetap hanya satu dakwaan yang akan dibuktikan. Pembuktian dakwaan tidak perlu dilakukan secara berurut sesuai lapisan dakwaan, tetapi langsung kepada dakwaan yang dipandang terbukti. Apabila salah satu telah terbukti maka dakwaan pada lapisan lainnya tidak perlu dibuktikan lagi.

c. Dakwaan Subsidair

Susunan dakwaan subsidair ini umumnya dalam lingkup suatu perbuatan yang parallel atau satu jurusan yang dalam dakwaan disusun berdasar pada urutan berat ringannya perbuatan yang tentu akan berbeda tentang berat ringan ancaman pidananya. Dalam dakwaan ini terdiri dari beberapa lapisan dakwaan yang disusun secara berlapis dengan maksud lapisan yang satu berfungsi sebagai pengganti lapisan sebelumnya. Sistematik lapisan disusun secara 
berurut dimulai dari tindak pidana yang diancam dengan pidana terberat sampai dengan tindak pidana yang diancam dengan pidana teringan. Pembuktian dilakukan secara berurut dimulai dari lapisan teratas sampai dengan lapisan terbawah.

d. Dakwaan Kumulatif

Bentuk surat dakwaan ini terdapat beberapa tindak pidana masing-masing berdiri sendiri artinya tidak ada hubungan antara tindak pidana yang satu tehadap yang lain dan didakwakan secara serempak. Dalam hal ini didakwakan beberapa tindak pidana sekaligus dari kesemua dakwaan harus dibuktikan satu demi satu. Tindak pidana yang didakwakan masing-masing berdiri sendiri, tetapi didakwakan secara serempak asal saja pelaku dari tindak pidana itu adalah sama. Dakwaan yang tidak terbukti harus dinyatakan secara tegas dan dituntut pembebasan dari dakwaan tersebut. Dakwaan ini dipergunakan dalam hal terdakwa melakukan beberapa tindak pidana yang masing-masing merupakan tindak pidana yang berdiri sendiri.

e. Dakwaan Kombinasi atau Gabungan

Dakwaan kombinasi adalah merupakan kombinasi dari dakwaan yang berbentuk alternatif dengan dakwaan subsidair atau antara dakwaan komulatif dengan dakwaan subsidair atau antara dakwaan komulatif dengan dakwaan alternatif, dan sebagainya. Dakwaan ini harus diperhatikan secara teliti mengenai bentuk-bentuk dari kumulasinya, dan jangan sampai upaya untuk mencegah terdakwa lepas dari dakwaan.Timbulnya bentuk ini seiring dengan perkembangan di bidang kriminalitas yang semakin variatif baik dalam bentuk atau jenisnya maupun dalam modus operandi yang dipergunakan.

Berkaitan dengan kasus yang telah disidang melalui Putusan Pengadilan Negeri Stabat No. 10/Pid.Sus Anak/2015/PN.Stb, maka Jaksa Penuntut Umum merumuskan surat dakwaan dalam bentuk dakwaan alternatif, yaitu :

Kesatu :

Perbuatan Anak sebagaimana diatur dan diancam pidana melanggar Pasal 115 ayat (2) Undang-Undang RI No. 35 tahun 2009 Tentang Narkotika Jo UndangUndang RI No.11 Tahun 2102 Tentang Sistem Peradilan Pidana Anak.

Pasal 115 ayat (2) UU Narkotika berbunyi :

Dalam hal perbuatan membawa, mengirim, mengangkut, atau mentransito Narkotika Golongan I sebagaimana dimaksud pada ayat (1) dalam bentuk tanaman beratnya melebihi 1 (satu) kilogram atau melebihi 5 (lima) batang pohon beratnya melebihi 5 (lima) gram, pelaku dipidana dengan pidana penjara seumur hidup atau pidana penjara paling singkat 5 (lima) tahun dan paling lama 20 (dua puluh) tahun dan pidana denda maksimum sebagaimana dimaksud pada ayat (1) ditambah 1/3 (sepertiga).

Atau Kedua :

Perbuatan Anak sebagaimana diatur dan diancam pidana melanggar Pasal 114 ayat (2) Undang-Undang RI No.35 tahun 2009 Tentang Narkotika Jo UndangUndang RI No.11 Tahun 2102 Tentang Sistem Peradilan Pidana Anak.

Pasal 114 ayat (2) UU Narkotika berbunyi : 
Dalam hal perbuatan menawarkan untuk dijual, menjual, membeli, menjadi perantara dalam jual beli, menukar, menyerahkan, atau menerima Narkotika Golongan I sebagaimana dimaksud pada ayat (1) yang dalam bentuk tanaman beratnya melebihi 1 (satu) kilogram atau melebihi 5 (lima) batang pohon atau dalam bentuk bukan tanaman beratnya 5 (lima) gram, pelaku dipidana dengan pidana mati, pidana penjara seumur hidup, atau pidana penjara paling singkat 6 (enam) tahun dan paling lama 20 (dua puluh) tahun dan pidana denda maksimum sebagaimana dimaksud pada ayat (1) ditambah 1/3 (sepertiga).

Atau Ketiga :

Perbuatan anak sebagaimana diatur dan diancam pidana melanggar Pasal 111 ayat (2) Undang-Undang RI No.35 tahun 2009 Tentang Narkotika Jo UndangUndang RI No.11 Tahun 2102 Tentang Sistem Peradilan Pidana Anak.

Pasal 111 ayat (2) UU Narkotika berbunyi :

Dalam hal perbuatan menanam, memelihara, memiliki,menyimpan, menguasai, atau menyediakan Narkotika Golongan I dalam bentuk tanaman sebagaimana dimaksud pada ayat (1) beratnya melebihi 1 (satu) kilogram atau melebihi 5 (lima) batang pohon, pelaku dipidana dengan pidana penjara seumur hidup atau pidana penjara paling singkat 5 (lima) tahun dan paling lama 20 (dua puluh) tahun dan pidana denda maksimum sebagaimana dimaksud pada ayat (1) ditambah $1 / 3$ (sepertiga).

Kemudian Majelis memutus terdakwa dengan "Menyatakan anak Muhajir Alias Bulek telah terbukti secara sah dan meyakinkan bersalah melakukan tindak pidana" Tanpa hak dan melawan hukum menjadi perantara jual beli Narkotika Golongan I dalam bentuk tanaman",sebagaimana dalam dakwaan Pasal 114 ayat(2) Undang Undang RI No. 35 tahun 2009 tentang Narkotika Jo Undang Undang RI No. 11 Tahun 2012 tentang Sistem Peradilan Anak".

Di dalam Pasal 114 ayat (2) UU Narkotika terdapat beberapa bentuk perbuatan, yaitu menawarkan untuk dijual, menjual, membeli, menjadi perantara dalam jual beli, menukar, menyerahkan, atau menerima Narkotika Golongan I. Menawarkan menurut kamus Besar Bahasa Indonesia adalah mengunjukkan sesuatu kepada (dengan maksud supaya dibeli, dikontrak, diambil, dipakai). Menjual menurut Kamus Besar Bahasa Indonesia adalah memberikan sesuatu kepada orang lain untuk memperoleh uang pembayaran atau menerima uang. Membeli menurut Kamus Besar Bahasa Indonesia adalah memperoleh sesuatu melalui penukaran (pembayaran) dengan uang. Menjadi perantara dalam jual beli menurut Kamus Besar Bahasa Indonesia adalah pialang; makelar; calo (dalam jual beli dan sebagainya). Menukar Kamus Besar Bahasa Indonesia adalah mengganti (dengan yang lain); menyilih; mengubah (nama dan sebagainya); memindahkan (tempat dan sebagainya). Menyerahkan menurut Kamus Besar Bahasa Indonesia adalah memberikan (kepada); menyampaikan (kepada): memberikan dengan penuh kepercayaan; memasrahkan. Menerima menurut Kamus Besar Bahasa Indonesia adalah menyambut; mengambil (mendapat, menampung, dan sebagainya) sesuatu yang diberikan, dikirimkan, dan sebagainya. 
Pertimbangan hakim di dalam menjatuhkan Pasal 114 ayat (2) UU Narkotika dalam bentuk perbuatan menjadi perantara dalam jual beli adalah menimbang, bahwa Anak telah didakwa oleh Penuntut Umum dengan dakwaan yang berbentukalternatif, yaitu Pasal 115 ayat(1) UURI No. 35 Tahun2009 jo. UURI No. 11 Tahun 2012 tentang SPPA atau Pasal 114 ayat(1) UURI No. 35 Tahun 2009 jo. UURI No. 11 Tahun 2012 tentang SPPA atau pasal 111ayat(2) UURI No. 35 Tahun 2009 jo. UURI No. 11 Tahun 2012 tentang SPPA sehingga Majelis Hakim dengan memperhatikan fakta-fakta hukum tersebut diatas akan memilih langsung dakwaan Jaksa Penuntut Umum sebagaimana diatur dalam Pasal 114 ayat(1) UURI No. 35 tahun 2009 tentang Narkotika jo. UURI No. 11 tahun 2012 tentang SPPA yang unsur-unsurnya adalah sebagai berikut:

1. Setiap Orang.

2. Tanpa Hak dan Melawan Hukum memiliki, menyimpan, menguasai, atau menyediakan Narkotika Gol. I jenis ganja yang dilakukan oleh Anak.

Menimbang, bahwa terhadap unsur-unsur tersebut Majelis Hakim mempertimbangkan sebagai berikut:

\section{Ad. 1. Setiap Orang}

Bahwa yang dimaksud Setiap orang adalah sama dengan pengertian "barang siapa" sebagaimana diatur dalam Kitab Undang-Undang Hukum Pidana adalah subjek hukum yang dapat berupa orang-perorangan maupun badan hukum yang diwakili oleh person yang menampakkan daya berfikir sebagai persyaratan mendasar kemampuan bertanggungjawab, yang berdasarkan ketentuan dalam Pasal 44 ayat (1) KUHP dapat diketahui bahwa orang yang dipandang mampu mempertanggung jawabkan perbuatan yang dilakukannya adalah orang yang sehat akal pikirannya;

Menimbang, yang menjadi subjek hukum yang diajukan kepersidangan karena didakwa telah melakukan tindak pidana adalah berupa orang yaitu Anak bernama Muhajir alias Bulek sesuai dengan identitasnya dalam Surat Dakwaan dan Anak juga membenarkan identitasnya dalam Surat Dakwaan Penuntut Umum tersebut, sehingga Hakim berpendapat Anak sebagaimana tercantum dalam Surat Dakwaan Jaksa Penuntut Umum dalam perkara a quo adalah benar dan bukan orang lain daripadanya sehingga tidak terjadi error in persona, dengan demikian unsur setiap orang ini telah terpenuhi;

Ad.2. Tanpa Tanpa Hak dan Melawan Hukum memiliki, menyimpan, menguasai,atau menyediakan Narkotika Gol. I jenis ganja yang dilakukan oleh Anak;

Menimbang, bahwa unsur ini telah mengatur tentang beberapa perbuatan yang dilarang yang bersifat alternatif sehubungan dengan peredaran Narkotika Golongan I. Sementara itu, sesuai dengan fakta di persidangan dan dihubungkan pula bahwa berdasarkan berita acara penimbangan barang bukti dari PT.Pegadaian Pangkalan Brandan No. 30/IL.010700/IX/2015 tanggal 15 Oktober 
2015 dengan hasil penimbangan barang bukti berupa 15 bal/bunngkus besar yang dibawa oleh anak anak Muhajir aias Bulek diduga berisikan Narkotika jenis ganja kering memiliki berat kotor 16.500 (enam belas ribu lima ratus) gram, dan disisihkan untuk keperluan Laboratorium Narkotika Medan seberat 129 (seratus dua puluh sembilan) gram dan berdasarkan berita acara anlisis laboratorium barang bukti narkotika medan No. Lab:9580/NNF/2015 tanggal 19 Oktober 2015 menyimpulkan bahwa barang bukti berupa : 1(satu) plastik bening berisi daun dan biji kering dengan berat netto 129 (seratus dua puluh sembilan) gram dan pengembalikan barang bukti sesudah labfor dengan berat adalah benar positif ganja dan terdaftar dalam golongan I(satu) nomor urut 8 lampiran 1 UndangUndang RI No. 35 tahun 2009 tentang Narkotika dengan demikian unsur Narkotika Golongan I telah terpenuhi dalam perkara ini;

Menimbang, bahwa unsur ini telah mengatur beberapa perbuatan yang dilarang yaitu meliputi perbuatan memiliki, menyimpan, menguasai atau menyediakan narkotika golongan I dalam bentuk tanaman. Adapun perbuatan tersebut dilarang karena adanya batasan-batasan maupun syarat-syarat yang telah ditentukan oleh UU No. 35 Tahun 2009 Tentang Narkotika yang mengatur tentang peredaran Narkotika sebagaimana diatur dalam Pasal 38 disebutkan bahwa"Setiap kegiatan peredaran Narkotika wajib dilengkapi dengan dokumen yang sah";

Menimbang, bahwa berdasarkan fakta yang terungkap di persidangan sebagai berikut :

- Bahwa pada hari Kamis tanggal 15 Oktober 2015 sekitar pukul 04.30 wib bertempat di Depan Pos Lantas Polsek Gebang di Jalan Lintas Sumatera Dusun III Desa Paluh Manis Kecamatan Gebang Kabupaten Langkat anak ditangkap pihak kepolisan karena membawa ganja.

- Bahwa benar ketika personil Polsek Gebang melakukan sweeping terhadap kendaraan yang lewatdan pada saat itu para saksi Polisi menghentikan bus PT. Putra Pelangi Perkasa BL 7520 AA.

- Bahwa benar kemudian saksi Anggiat Simanjuntak dan saksi Aldolf Simanjuntak masuk ke dalam bus melakukan pemeriksaan terhadap bawaan para penumpang bus,

- Bahwa benar ketika sampai pada tempat duduk nomor 21/22, dimanaanak duduk, saksi Anggiat Simanjuntak dan saksi Aldolf Simanjuntak meminta anak untuk membuka tas ransel hitam merk Elgini milik anak.

- Bahwa benar Tas diperiksa ketika dibuka ditemukan 4(empat) bal Narkotika Golongan I jenis ganja kering dibalut lakban kuning.

- Bahwa benar para saksi tanyai kepada kepada anak dimana lagidisimpan ganja tersebut, anak mengaku menyimpan ganja dalam kardus pop mie di bagasi bus sebelah kiri.

- Bahwa benar kemudian anak dibawa untuk menunjukkan kardus bawan anak, dan ketika dibuka kardus bawaan anak tersebut ditemukan lagi barang 
bukti berupa Narkotika Golongan I jenis Ganja sebanyak 11 bal yang dibalut lakban kuning yang anak bawa dari Lokseumawe.

- Bahwa benar ketika saksi tanya anak mengaku bahwa 15 bal ganja kering tersebut dibawa dari Sawang(Aceh) menuju Medan dan ganja tersebut milik Hamdan(DPO) .

- Bahwa anak hanya bertugas sebagai kurir dengan upah Rp.100.000,-(seratus ribu rupiah) per kilogram atau per bal nya.

- Bahwa berdasarkan berita acara penimbangan barang bukti dari PT.Pegadaian Pangkalan Brandan No. 30/IL.010700/IX/2015 tanggal15 Oktober 2015 dengan hasil penimbangan barang bukti berupa 15 bal/bunngkus besar yang dibawa oleh anak anak Muhajir aias Bulek diduga berisikan Narkotika jenis ganja kering memiliki berat kotor 16.500 (enam belas ribu lima ratus) gram, dan disisihkan untuk keperluan Laboratorium Narkotika Medan seberat 129 (seratus dua puluh sembilan) gram.

- Bahwa berdasarkan berita acara anlisis laboratorium barang bukti narkotika medan No. Lab:9580/NNF/2015 tanggal 19 Oktober 2015menyimpulkan bahwa barang bukti berupa : 1(satu) plastik bening berisi daun dan biji kering dengan berat netto 129 (seratus dua puluh sembilan) gram dan pengembalikan barang bukti sesudah labfor dengan berat adalah benar positif ganja dan terdaftar dalam golongan I(satu) nomor urut 8 lampiran 1 Undang-Undang RI No. 35 tahun2009 tentang Narkotika.

Menimbang, bahwa dalam hal ini UU No. 35 Tahun 2009 tentang Narkotikasecara limitatif telah membuat pembatasan bahwa yang dapat memiliki,menyimpan, menguasai, menyediakan hanyalah pedagang besar farmasi tertentu, lembaga ilmu pengetahuan dan sarana penyimpanan sediaan farmasi pemerintah. Sedangkan tujuan peredaran Narkotika, terutama Narkotika Golongan I hanya terbatas pada kepentingan ilmu pengetahuan dan pengembangan teknologi;

Menimbang, bahwa dengan demikian, unsur tanpa hak atau melawan hukum sebagaimana dimaksud dalam Pasal 114 ayat(1) UU No. 35 Tahun2009 Tentang Narkotika adalah setiap perbuatan yang tidak sesuai dengan ketentuan Pasal 35 jo Pasal 8, Pasal 41 dan Pasal 38 UU No.35 Tahun 2009Tentang Narkotika merupakan suatu perbuatan yang dilakukan secara tanpa hak atau bertentangan dengan peraturan perundangan yang berlaku atau bertentangan dengan hak orang lain;

Menimbang, bahwa benar Anak tidak ada memiliki izin yang sah untuk menyimpan narkotika jenis sabu tersebut;

Menimbang, bahwa berdasarkan hal-hal diatas, Majelis Hakim berpendapat bahwa perbuatan Anak yang memilki Narkotika jenis sabu tersebut merupakan perbuatan yang bertentangan dan tidak sejalan dengan ketentuan yang diatur oleh UU No. 35 Tahun 2009 Tentang Narkotika. Dengan demikian unsur tanpa hak dan melawan hukum memiliki Narkotika Golongan I dalan bentuk tanaman telah terpenuhi dalam perbuatan Anak; 
Menimbang, bahwa oleh karena semuaunsur dari Pasal 114 ayat(1) UU RI No. 35 Tahun 2009 tentang Narkotika telahterpenuhi, maka Anak haruslah dinyatakan telah terbukti secara sah dan meyakinkan melakukan tindak pidana sebagaimana didakwakan dalam dakwaan alternatif kedua.

Putusan Majelis Hakim tidak sesuai dengan surat dakwaan Jaksa Penuntut Umum.

Padahal tujuan dan guna surat dakwaan adalah sebagai dasar dan landasan pemeriksaan di dalam sidang pengadilan. Hakim di dalam memeriksa suatu perkara tidak boleh menyimpang menyimpang dari apa yang dirumuskan dalam surat dakwaan. dengan demikian, seorang terdakwa yang dihadapkan ke sidang pengadilan hanya dapat dijatuhi hukuman karena telah terbukti melakukan tindak pidana seperti yang disebutkan atau yang dinyatakan oleh Jaksa Penuntut Umum dalam surat dakwaan. Fungsi surat dakwaan bagi hakim Surat dakwaan bagi hakim merupakan dasar pemeriksaan, membatasi ruang lingkup pemeriksaan, dasar pertimbangan dan dasar pengambilan keputusan tentang bersalah tidaknya terdakwa dalam tindak pidana yang didakwakan kepadanya.

Melihat pada pertimbangan di atas, maka dasar hukum yang digunakan oleh Majelis Hakim sangat keliru karena tidak sinkron dengan isi dari dakwaan yang kedua. Di mana di dalam dakwaan yang kedua Jaksa Penuntut Umum mendakwa dengan Pasal 114 ayat (2) UU Narkotika, sementara Majelis Hakim di dalam pertimbangannya menguraikan tentang unsur-unsur tindak pidana yang terdapat di dalam Pasal 112 ayat (1) UU Narkotika, yaitu dalam bentuk memiliki tanpa izin. Padahal di dalam amar putusannya Majelis Hakim menyatakan bahwa terdakwa terbuki secara sah dan meyakinkan menjadi perantara dalam jual beli.

\section{Jenis Pidana yang Dijatuhkan Oleh Majelis Hakim dalam Putusan Pengadilan Negeri Stabat No. 10/Pid.Sus Anak/2015/PN.Stb}

Sistem pemidanaan yang sampai sekarang terkadang masih memperlakukan anak-anak yang terlibat sebagai pelaku tindak pidana itu seperti pelaku tindak pidana yang dilakukan oleh orang dewasa. Anak ditempatkan dalam posisi sebagai seorang pelaku kejahatan yang patut untuk mendapatkan hukuman yang sama dengan orang dewasa dan berlaku di Indonesia. Pemidanaan itu sendiri lebih berorientasi kepada individu pelaku atau biasa disebut dengan pertanggungjawaban individual atau personal dimana pelaku dipandang sebagai individu yang mampu untuk bertanggung jawab penuh terhadap perbuatan yang dilakukannya. Sedangkan anak merupakan individu yang belum dapat menyadari secara penuh atas tindakan atau perbuatan yang dilakukannya, hal ini disebabkan karena anak merupakan individu yang belum matang dalam berpikir. Oleh sebabitu dengan memperlakukan anak itu sama dengan orang dewasa maka dikhawatirkan si anak akan dengan cepat meniru perlakuan dari orangorang yang ada di dekatnya.

Ada tiga teori tujuan pemidanaan yang terkenal, yaitu teori absolute (teori pembalasan), teori relative (teori tujuan) dan teori gabungan.

1. Teori absolute atau teori pembalasan atau teori retributive. 
Teori ini melegitimasi pemidanaan sebagai sarana pembalasan atas kejahatan yang telah dilakukan seseorang. Kejahatan dipandang sebagai perbuatan yang immoral dan asusila di dalam masyarakat, oleh karena itu pelaku kejahatan harus dibalas dengan menjatuhkan pidana. Tujuan pemidanaan dilepaskan dari tujuan apapun, sehingga pemidanaan hanya mempunyai satu tujuan, yaitu pembalasan (Bammelen, 1997: 25).

Menurut Remmelink, teori retributive atau teori absolute dapat dikatakan sama tuanya dengan pemikiran tentang pidana. Syarat pembenaran penjatuhan pidana tercakup dalam kejahatan itu sendiri. Pemikiran ini beranjak dari pandangan yang absolute terhadap pidana. Dalam konteks ajaran ini, pidana merupakan rez absoluta ab affectu futuro (suatu keniscayaan yang terlepas dari dampaknya di masa depan). Dilakukkanya kejahatan, maka membawa konsekuensi dijatuhkannya pemidanaan (Remmelink, 1993: 600).

Penjatuhan pidana pada pelaku kejahatan dalam teori retributive ini, menurut Romli Atmasasmita mempunyai sandaran pembenaran sebagai berikut (Atmasasmita, 1995: 83-84):

1) Dijatuhkannya pidana akan memuaskan perasaan balas dendam si korban, baik perasaan adil bagi dirinya, temannya, maupun keluarganya. Perasaan ini tidak dapat dihindari dan tidak dapat dijadikan alasan untuk menuduh tidak menghargai hukum. Tipe aliran retributive ini disebut vindicative

2) Penjatuhan pidana dimaksudkan sebagai peringatan kepada pelaku kejahatan dan anggota masyarakat yang lainnya bahwa setiap perbuatan yang merugikan orang lain atau memperoleh keuntungan dari orang lain secara tidak wajar, maka akan menerima ganjarannya. Tipe aliran retributive ini disebut fainess.

3) Pidana dimaksudkan untuk menunjukkan adanya kesebandingan antara bertanya suatu pelanggaran dengan pidana yang dijatuhkan. Tipe aliran retributive ini disebut proportionality.

2. Teori relative atau teori tujuan

Teori memandang bahwa pemidanaan mempunyai tujuan lain yang lebih berarti dari tujuan pembalasan, yaitu perlindungan masyarakat dan pencegahan kejahatan, baik prevensi umum maupun prevensi khusus. Tujuan pemidanaan untuk prevensi umum diharapkan memberikan peringatan kepada masyarakat supaya tidak melakukan kejahatan. Prevensi umum ini menurut van Veen mempunyai tiga fungsi, yaitu menegakkan wibawa pemerintah, menegakkan norma dan membentuk norma. Prevensi khusus dimaksudkan bahwa dengan pidana yang dijatuhkan, menberikan deterrence effect kepada si pelaku sehingga tidak mengulangi perbuatannya kembali. Sedangkan fungsi perlindungan kepada masyarakat memungkinkan bahwa dengan pidana pencabutan kebebasan selama waktu tertentu, maka masyarakat akan 
terhindar dari kejahatan yang mungkin dilakukan oleh pelaku (Bemmelen, 1997 :28).

3. Teori gabungan

Teori ini berusaha mencari jalan dan menemukan benang merah antara kedua teori di atas. Teori gabungan mengakui bahwa pembalasan (retrivutif) merupakan dasar dan pembenaran dijatuhkannya pidana, namun seharusnya perlu diperhatikan bahwa penjatuhan pidana harus membawa manfaat untuk mencapai tujuan lain, misalnya kesejahteraan masyarakat (social welfare). Teori ini mencoba menyatukan tujuan pemidanaan sebagai pembalasan dan juga untuk pencegahan. Kedua tujuan ini merupakan gabungan antar teori retributive dan teori relative di atas. Ketiga teori ini masih mengakui peranan pidana dalam menanggulangi kejahatan, tinggal menempatkan tujuan pidana ini secara proporsional (Bemmelen, 1997 :28).

Anak sebagai individu yang belum dewasa perlu mendapatkan perlindungan hukum/yuridis (legal protection) agar terjamin kepentingannya sebagai anggota masyarakat. Masalah penegakan hak-hak anak dan hukum anak, pada dasarnya sama dengan masalah penegakkan hukum secara keseluruhan. Oleh karena itu, masalah pengimplementasian hukum anak dipengaruhi oleh beberapa faktor-faktor (Tanamas, 1999: 90):

1. Peraturan hukumnya, yakni peraturan perundang-undangan yang mengatur tentang masalah hukum tertentu. Dalam hal ini, masalah peraturan hukum tentang hak-hak anak berkenaan dengan :

a. Cara pembentukan dan persyaratan yuridis pembentukannya.

b. Materi hukum tersebut apakah telah sesuai dengan semangat, nilai, asas, atau kaidah hukumnya maupun sanksi hukumnya.

c. Peraturan pelaksanaan yang dikehendaki perlu dipersiapkan untuk mencegah kekosongan hukum.

Aparat penegak hukum, yakni para petugas hukum atau lembaga yang berkaitan dengan proses berlangsungnya hukum dalam masyarakat. Dalam hal penegakkan hukum di Indonesia, aparat yang bertugas menegakkan hukum dikenal dengan

2. catur wangsa yang meliputi kepolisian (lembaga penyidik), kejaksaan (penuntut), hakim (peradilan), dan pengacara atau advokat. Untuk menegakkanhak-hak anak dan menegakkan hukum anak, menghadapi permasalahan umum yang melanda Indonesia yakni keterbatasan kemampuan para penegak hukum yang memahami hukum anak dan hak-hak anak, kualitas, pendidikan dan keahlian masing-masing aparat penegak hukum, dan kemampuan organisasi dalam menegakkan hukum anak dan hak-hak anak.

3. Budaya hukum masyarakat, yakni struktur sosial dan pandangan kultural yang berlangsung dan diyakini masyarakat dalam menegakkan hukum sebagai sebuah pedoman tingkah laku sehari-hari. Masalah budaya hukum merupakan masalah 
penting dalam menegakkan hukum di Indonesia yang menyangkut keyakinan masyarakat pada hukum dan para penegak hukum.

4. Masyarakat hukum, yakni tempat bergeraknya hukum dalam kehidupan seharihari yang mencakup dengan sejauh mana kepatuhan masyarakat kepada hukum, kepedulian masyarakat untuk menegakkan hukum untuk menuju ketertiban dan kedamaian. Dalam hal penegakkan hak-hak anak dalam praktek kehidupan sehari-hari. Hukum anak hanya pedoman yang bisa dijadikan acuan untuk mengarahkan bagaimana masyarakat bertindak jika masalah anak ditemukan.

Menurut Undang-Undang Nomor 11 Tahun 2012 tentang Sistem Peradilan Pidana Anak, terhadap anak yang berkonflik dengan hukum (anak sebagai pelaku) hanya dapat dijatuhkan pidana atau tindakan. Adapun pidana yang dapat dijatuhkan kepada Anak menurut Pasal 71 UU No. 11 Tahun 2012 adalah:

Pidana pokok bagi Anak terdiri atas:

a. Pidana peringatan;

b. Pidana dengan syarat:

1) pembinaan di luar lembaga;

2) pelayanan masyarakat; atau

3) pengawasan.

c. Pelatihan kerja;

d. Pembinaan dalam lembaga; dan

e. Penjara.

Pidana tambahan terdiri atas:

a. Perampasan keuntungan yang diperoleh dari tindak pidana; atau

b. Pemenuhan kewajiban adat.

Untuk sanksi tindakan yang dapat dijatuhkan kepada anak sebagaimana dimaksud di dalam Pasal 82 UU No. 11 Tahun 2012 adalah

a. Pengembalian kepada orang tua/Wali;

b. Penyerahan kepada seseorang;

c. Perawatan di rumah sakit jiwa;

d. Perawatan di LPKS;

e. Kewajiban mengikuti pendidikan formal dan/atau pelatihan yang diadakan oleh pemerintah atau badan swasta;

f. Pencabutan surat izin mengemudi; dan/atau

g. Perbaikan akibat tindak pidana.

Di dalam menjatuhkan jenis dan besarnya pidana, Majelis Hakim menggunakan perimbangannya sebagai berikut :

1. Bahwa Pasal 81 ayat(5) UU No. 11 Tahun 2012 tentang SPPA menentukan pidana penjara terhadap Anak hanya digunakan sebagai upaya terakhir;

2. Bahwa penjatuhan pidana bukanlah bersifat pembalasan melainkan sebagai usaha preventif dan represif atau lebih tegas lagi pidana yang dijatuhkan bukanlah untuk menurunkan martabat Anak, tetapi adalah bersifat edukatif, konstruktif dan motivatif dengan harapan agar Anak tersebut tidak 
mengulangi perbuatannya kelak setelah selesai menjalani pidana yang dijatuhkan dan merupakan prevensi bagi masyarakat lainnya

3. Bahwa oleh karena anak dijatuhi pidana maka haruslah dibebani pula untuk membayar biaya perkara;

4. Bahwa laporan hasil penelitian kemasyarakatan atas diri Anak tersebut telah pula menguraikan tentang bagaimana kehidupan Anak, keluarga dan lingkungannya serta latar belakang terjadinya tindak pidana tersebut, dan laporan penelitian kemasyarakatan menyarankan agar Anak dijatuhi pidana seringan-ringannya jika dinyatakan bersalah, sehingga oleh karena itu Hakim menilai tuntutan Penuntut Umum yakni tentang jenis penjatuhan pidana dan masa pidana yang akan dijatuhkan kepada Anak tersebut sudah dianggap ringan, dengan mempertimbangkan hal-hal yang memberatkan dan meringankan yaitu:

Keadaan yang memberatkan :

- Perbuatan Anak tidak mendukung program Pemerintah dalam memberantas Narkoba.Keadaan yang meringankan :

- Anak menyesali perbuatannya dan berjanji tidak akan mengulanginya lagi;

- Anak belum pernah dihukum.

5. Bahwa oleh karenanya Hakim akan memilih penjatuhan pidana yang paling tepat untuk Anak;

6. Bahwa Pasal 71 ayat (1) huruf b angka 3 UU No. 11 Tahun 2012 tentang Sistem Peradilan Pidana Anak(selanjutnya disingkat SPPA) menentukan pidana pokok bagi Anak terdiri atas pidana dengan syarat dengan pengawasan;

7. Bahwa Pasal 73 ayat (3) UU No. 11 Tahun 2012 tentang SPPA menentukan agar Anak tidak akan melakukan tindak pidana lagi selama masa pidana dengan syarat;

8. Bahwa Pasal 77 ayat (2) UU No. 11 Tahun 2012 tentang SPPA menentukan dalam hal Anak dijatuhi pidana pengawasan. Anak ditempatkan di bawah pengawasan Penuntut Umum dan dibimbing oleh Pembimbing Kemasyarakatan;

9. Bahwa setelah menguraikan mengenai pidana yang akan dijatuhkan, menurut hemat Hakim, jenis pidana yang paling tepat dijatuhkan kepada Anak adalah pidana dengan syarat dengan pengawasan;

Apabila melihat jenis pidana yang dijatuhkan oleh Majelis Hakim di dalam Putusan Pengadilan Negeri Stabat No. 10/Pid.Sus Anak/2015/PN.Stb sebagaimana yang terdapat di dalam amar putusannya adalah "Menjatuhkan pidana terhadap anak Muhajir Alias Bulek oleh karena itu dengan pidana penjara selama 4 (empat) tahun dan denda sebesar Rp. 1.000.000.000,-(satu milyar rupiah) dengan ketentuan apabila anak tidak membayar denda tersebut akan diganti dengan menjalani pelatihan kerja selama 2(dua) bulan". 
Dengan demikian, maka terdapat dua bentuk pidana yang dijatuhkan oleh Majelis Hakim dalam bentuk kumulatif, yaitu pidana penjara selama 4 tahun dan pidana denda sebesar Rp. 1.000.000.000,-(satu milyar rupiah). Apabila pidana denda tidak dapat dibayar oleh anak, maka akan diganti dengan menjalani pelatihan kerja selama 2 (dua) bulan".

Apabila melihat pada ketentuan ancaman pidana yang terdapat di dalam Pasal 114 ayat (2) UU Narkotika, maka pidana yang dijatuhkan oleh Majelis Hakim tidak bertentangan dengan uu. Di mana ancaman pidananya adalah pidana mati, pidana penjara seumur hidup, atau pidana penjara paling singkat 6 (enam) tahun dan paling lama 20 (dua puluh) tahun dan pidana denda maksimum sebagaimana dimaksud pada ayat (1) ditambah 1/3 (sepertiga). Pidana denda menurut ayat (1) nya adalah paling sedikit Rp1.000.000.000,00 (satu miliar rupiah) dan paling banyak Rp10.000.000.000,00 (sepuluh miliar rupiah). Dengan demikian, maka hakim dapat memutu pidana denda maksimum ditambag $1 / 3$ sehingga pidana denda maksimum menjadi sekitar Rp. 13.000.000.000.

Namun apabila pidana yang dijatuhkan oleh Majelis Hakim dihubungkan dengan pertimbangannya, maka terdapat ketidaksesuain yaitu pada pertimbangnnya Majelis Hakim menilai bahwa pidana yang tepat untuk dijatuhkan adalah pidana pengawasan sebagaimana diatur di dalam Pasal Pasal 71 ayat (1) huruf b angka 3 dan Pasal 77 ayat (2) UU No. 11 Tahun 2012, sementara di dalam amar putusannya Majelis Hakim menjatuhkan pidana penjara dan denda.

Dilihat dari ketentuan sistem pemidaan terhadap anak yang terdapat di dalam UU No. 11 Tahun 2012, maka penjatuhan pidana denda itu bertentangan dengan uu. Di mana pada Pasal 71 ayat (3) UU No. 11 Tahun 2012 menyatakan "Apabila dalam hukum materiil diancam pidana kumulatif berupa penjara dan denda, pidana denda diganti dengan pelatihan kerja". UU No. 11 Tahun 2012 tidak mengenal adanya pidana denda kepada anak, sehingga sudah tidak selayaknya Hakim menjatuhkan pidana denda kepada anak. Dalam memahami ketentuan Pasal 71 ayat (3) UU No. 11 Tahun 2012 tersebut, maka sikap Majelis Hakim yang seharusnya adalah dapat menjatuhkan pidana penjara dan pidana pelatihan kerja tanpa menyebutkan terlebih dahulu pidana denda. Penerapan denda yang digunakan sebagai dasar bagi hakim dalam memutus tindak pidana anak masih dipengaruhi oleh paham positivistik / legalistik yang artinya menerapkan apa yang dinormakan di dalam Undang-undang.

\section{KESIMPULAN}

Pertimbangan hakim di dalam menjatuhkan Pasal 114 ayat (2) UU Narkotika sebagaimana yang terdapat di dalam Putusan Pengadilan Negeri Stabat No. 10/Pid.Sus Anak/2015/PN.Stb dalam bentuk perbuatan menjadi perantara dalam jual beli adalah tidak sesuai dengan pasal yang dipertimbangkan, yaitu di mana di dalam dakwaan yang kedua Jaksa Penuntut Umum mendakwa dengan Pasal 114 ayat (2) UU Narkotika, sementara Majelis Hakim di dalam pertimbangannya menguraikan tentang unsur-unsur tindak pidana yang terdapat di dalam Pasal 112 ayat (1) UU Narkotika, yaitu dalam 
bentuk memiliki tanpa izin. Padahal di dalam amar putusannya Majelis Hakim menyatakan bahwa terdakwa terbuki secara sah dan meyakinkan menjadi perantara dalam jual beli.

Di dalam Putusan Pengadilan Negeri Stabat No. 10/Pid.Sus Anak/2015/PN.Stb Majelis Hakim menjatuhkan pidana dengan merujuk pada Pasal 114 ayat (2) UU Narkotika dalam bentuk kumulatif, yaitu pidana penjara selama 4 tahun dan pidana denda sebesar Rp. 1.000.000.000,-(satu milyar rupiah). Apabila pidana denda tidak dapat dibayar oleh anak, maka akan diganti dengan menjalani pelatihan kerja selama 2 (dua) bulan". Apabila pidana yang dijatuhkan oleh Majelis Hakim dihubungkan dengan pertimbangannya, maka terdapat ketidaksesuain yaitu pada pertimbangnnya Majelis Hakim menilai bahwa pidana yang tepat untuk dijatuhkan adalah pidana pengawasan sebagaimana diatur di dalam Pasal Pasal 71 ayat (1) huruf b angka 3 dan Pasal 77 ayat (2) UU No. 11 Tahun 2012, sementara di dalam amar putusannya Majelis Hakim menjatuhkan pidana penjara dan denda. Penjatuhan pidana denda itu bertentangan dengan Pasal 71 ayat (3) UU No. 11 Tahun 2012. UU No. 11 Tahun 2012 sebagaimana dimaksud di dalam Pasal 71 tidak mengenal adanya pidana denda kepada anak, sehingga sudah tidak selayaknya Hakim menjatuhkan pidana denda kepada anak.

\section{DAFTAR PUSTAKA}

Atmasasmita, Romli. (1995). Kapita Selekta Hukum Pidana dan Kriminologi. Bandung: Mandar Maju.

Bammelen, J.M. van. 1997. Hukum Pidana I. Bandung: Bina Cipta.

Harahap, M. Yahya. 2009. Pembahasan Permasalahan dan Penerapan KUHAP: Penyidikan dan Penuntutan. Jakarta: Sinar Grafika.

Putusan Pengadilan Negeri Stabat No. 10/Pid.Sus Anak/2015/PN.Stb.

Remmelink, Jan. (1993). Hukum Pidana, Komentar atas Pasal-pasal Terpenting dari KUHP Belanda dan Padanannya dalam KUHP Indonesia. Jakarta: Gramedi Pustaka Utama.

Tanamas, Joni, Moh dan Zulchaini Z. (1999). Aspek Hukum Perlindungan Anak, Bandung: PT Citra Aditya Bakti.

Undang-Undang Republik Indonesia Nomor 35 Tahun 2009 tentang Narkotika.

Undang-Undang Republik Indonesia Nomor 11 Tahun 2012 tentang Sistem Peradilan Pidana Anak. 